\title{
THE ROLE AND IMPORTANCE OF CAVE MICROCLIMATE IN THE SUSTAINABLE USE AND MANAGEMENT OF SHOW CAVES
}

\section{VLOGA IN POMEN JAMSKE MIKROKLIME PRI TRAJNOSTNI RABI IN UPRAVLJANJU TURISTIČNIH JAM}

\author{
Chris R. de FREITAS ${ }^{1}$
}

\begin{abstract}
UDC 551.581:551.44

Chris $R$. de Freitas: The role and importance of cave microclimate in the sustainable use and management of show caves Cave microclimate is important in the study of cave flora and fauna, certain karst processes underground and hydrogeologic aspects of speleothems; thus an understanding of microclimatic processes is especially important in the management of show caves. Here, examples are drawn from research on New Zealand caves and examined in the context of sustainable cave use management practices. The work considers that the cave manager is concerned, firstly, with defining the desired or optimal level or range of environmental conditions that should prevail and, secondly, with maintaining them. To do this requires an appropriate and reliable monitoring system. It involves selecting key indicators to be monitored and setting target standards. Selection of an appropriate monitoring system, however, relies on having a good understanding of the climate processes operating, essentially how they work and how they might be appropriately managed. Unlike microclimates in the atmosphere-land boundary layer, which are characterized by vertical exchanges, processes determining climate in all but nearly closed caves are dominated by advection of heat and moisture. It is this process that may give rise to distinct spatial and temporal patterns of climates in caves. Thermoadynamic aspects of external air-cave air interaction are assessed to explain spatial as well as short term and seasonal variations of thermal and moisture states of the cave atmosphere. The relevance of all this to cave management is discussed. It is argued that cave management is not simply a matter of determining usage levels or carrying capacity of caves; rather, it involves determining environmental management techniques that are appropriate to a particular cave condition or environmental state that should prevail.
\end{abstract}

Keywords: airflow, condensation, carbon dioxide, radon, cave management.

\footnotetext{
${ }^{1}$ School of Environment, University of Auckland, New Zealand, email: c.defreitas@auckland.ac.nz

Received/Prejeto: 01.03.2010
}

Izvleček UDK 551.581:551.44
Chris R. de Freitas: Vloga in pomen jamske mikroklime pri
trajnostni rabi in upravljanju turističnih jam Jamska mikroklima pomembno vpliva na razvoj in obstoj favne in flore ter vpliva ter na številne procese $\mathrm{v}$ jamah, kot npr. rasti kapnikov. Zato je razumevanje jamske mikroklime izjemno pomembno pri upravljanju turističnih jam. V članku predstavimo mikroklimatske raziskave $\mathrm{v}$ jamah na Novi Zelandij, predvsem $\mathrm{z}$ vidika njihovega trajnostnega upravljanja. Predpostavljamo, da upravnik jame želi poznati, kateri so za jamsko okolje pomembni parametri, kakšne so njihove optimalne vrednosti in kako jih vzdrževati v tem območju. Upravitelj za to potrebuje učinkovit sistem monitoringa, $\mathrm{z}$ vnaprej določenim naborom ključnih okoljskih kazalcev in njihovih ciljnih vrednosti. Izbor monitoringa zahteva predhodno poznavanje jamskih klimatskih procesov. Te in $\mathrm{z}$ njimi povezane prostorske in časovne spremembe parametrov, $\mathrm{v}$ največji meri določa advekcijski prenos toplote in vlage $\mathrm{v}$ jamah. Upravljanje jame ne pomeni zgolj določitev obremenilne sposobnosti jame, pač pa izbor in uporaba takega načina upravljanja, ki trajnostno zagotavlja potrebno stanje okolja.

Ključne besede: Trajnostno upravljanje, tok zraka $\mathrm{v}$ jamah, kondenzacija, ogljikov dioksid, temperatura, radon, upravljanje jam. 


\section{INTRODUCTION}

Tens of millions of people visit show caves (tourist caves) every year. Gillieson (1996) estimated the number of visitors globally around the end of the twentieth century to be over 20 million. At least five million people a year visit show caves in the United States alone (Aley 2010). Despite this huge audience, there are few well documented studies of visitor impact management as regards cave microclimate, and even fewer dealing with appropriate theory and management concepts along with descriptions of related environmental processes being managed.

The approach to managing show caves depends on the type of cave, in particular whether the cave or section of a cave is a low energy, stable environment. Caves or sections of caves that are active, high energy environments, such as those with a large throughput of water, are much less sensitive to internal human-induced change. On the other hand, these caves are often quite sensitive to external changes in the watershed catchment that is the source of water flowing through the cave. Relict caves and those parts of active caves that contain relict caverns and cave passage are usually low energy, stable environments that are potentially highly sensitive to change by human beings. The presence in a cave of just a few people, or the addition of an enlarged entrance way, or a gate or door, can change its energy and moisture regime. These affect the cave's temperature and humidity, but a range of other impacts are associated with human presence, and their effects are cumulative and often synergistic. The innate sensitivity of some caves to human presence led Aley (1976, cited by Gillieson 1996) to remark "the carrying capacity of a cave is zero." As far as show caves are concerned, however, the presence of people is clearly not optional unless the cave is to be closed to commercial use.

The microclimate of a cave is a key component of the cave's internal environment; thus it is important in the study of cave flora and fauna and cave ecosystems generally, certain karst processes underground and hydrogeologic aspects of speleothems. An understanding of microclimate processes is especially important in the management of heavily used show caves. Processes determining climate in all but nearly closed caves are primarily a function of advection of heat and moisture. It is this process of heat and moisture transfer that may give rise to distinct spatial and temporal patterns of climates in caves. Here thermodynamic aspects of external air-cave air interaction are assessed to explain spatial as well as short term and seasonal variations of thermal and moisture states of the cave atmosphere. The relevance of all this to cave management is explained. Examples are drawn from research on New Zealand caves, the Waitomo Glowworm Cave in particular, and examined in the context of sustainable management practices. It is argued that sustainable cave management is not simply a matter of determining usage levels or carrying capacity of caves; rather, it involves determining environmental management techniques that are appropriate to a particular cave condition or environmental state that should prevail.

\section{CONCEPTUAL FRAMEWORK}

Though widely used in management theory, the concept of "carrying capacity" hangs on the assumption that there is an upper limit to use that an area or resource can stand. However, this rarely applies in the case of show caves, as the resource base is not fixed and the pattern of such factors as timing and intensity of use are constantly changing. Also, impacts are not linear; for example, the effect of a group of 15 people may be more than three times the impact of a group of five. Furthermore, as Gillieson (1996) points out, the concept of maximum usage does not take into account the possible irreversibility of many ecosystem changes. For instance, cave fauna are frequently obligate species and habitat specialists that are vulnerable to minor changes of light, moisture and heat, and populations may not recover from a short term or longer term stress. Rather than being a matter of usage levels or carrying capacity, it is more one of determining environmental management techniques that are appropriate for a given cave. The real issue, therefore, is one of visitor impact management.

The cave manager is concerned, firstly, with defining the desired or optimal level or range of environmental conditions that should prevail and, secondly, with maintaining them. To do this requires an appropriate and reliable monitoring system. It involves selecting key indicators to be monitored and setting target standards; for example, a given range of temperature and humidity, a maximum allowable vapour pressure deficit (i.e. maximum rates of cave drying), or a maximum carbon dioxide level for particular cave conditions, concentrations above which may lead to corrosion and irreversible damage of calcite features of the cave. Criteria should 
also take into account sensitivities of cave fauna that are often dependent on very specific environmental conditions. Changes in heat, lighting, moisture and airflow may impact on populations directly or indirectly (such as on food supply) to such an extent that their survival is threatened. By this monitoring, cave managers can assess the consequences of change and modify management strategies accordingly. Selection of an appropriate monitoring system, however, relies on having a good understanding of the climate processes operating.

In the case of a commercial show cave, the concept of "cave monitoring" embraces measurement, observation and recording in the broadest sense and includes physical and biological (i.e. environmental) and social (i.e. visitor) variables. An essential part of identifying and selecting appropriate variables to be monitored is an understanding of physical and biological processes that compose the cave system; basically, how it works and what upsets it. Key reference criteria are concerned with defining optimal conditions and maintaining them. Identifying relevant questions with correct answers is the key to informed and effective sustainable use and management of show caves. These are: What to monitor? Where to monitor? How to monitor? The issues that arise are feasibility and cost of monitoring; choice and representativeness of key indicators; replication and frequency of measurement; quality control; plan for data analysis; and management standards and indicators of impact.

\section{THE WAITOMO GLOWWORM CAVE AS A MANAGEMENT MODEL}

The Waitomo Glowworm Cave (WGWC) is located in the Waitomo district of the North Island of New Zealand. It has a long history as a commercial show cave, first opening to tourists in 1889 , with electric lighting being installed as early as 1926 (Wilde 1986). Today the WGWC is a premier tourist attraction and the most visited cave in Australasia (de Freitas 1998; de Freitas \& Schmekal 2003). The cave is a particularly good candidate for a case study of sustainable management, as it is potentially more sensitive to both internal and external human impact than most other caves. This is because of its small size, its morphology, the large numbers of visitors and the presence of cave fauna crucial to its tourist appeal.

Given that cave management is for the most part visitor impact management, it is notable that more people visit the WGWC than any other cave in Australia or New Zealand. In recent times annual visitor numbers average just below 500,000. The next most visited cave is the much larger Lucas Cave that is part of the Jenolan Caves in New South Wales in Australia, which has an annual visitor rate that is less than a quarter of that for the WGWC. Between 1979 and 1994 there was a doubling of the number of people visiting the WGWC each year (de Freitas 1990, 1996), although numbers have fallen then stabilised over the past 15 years. However, from a management perspective it is important to note that visitor numbers are not evenly spread over an average visitor day or year. Twice as many people visit the WGWC during the high sun half of the year, and most visitors converge on the cave between 10:00 and 17:00 hours. On some days visitor numbers have exceeded 2,700, and in February, 1996 a record 66,593 people visited the WGWC, giving a staggering daily average of 2,296 at its peak in the 1990s (de Freitas 1996). Clearly, with this level of usage there is on-going potential for conflict to arise between the dual requirements of protecting and presenting the resource. Both the seasonal and daily peaks are highly relevant to cave management strategies.

The Waitomo region has a mild, sub-temperate climate. Mean daily maximum and minimum temperatures for the warmest month (January) are $24^{\circ} \mathrm{C}$ and $13^{\circ} \mathrm{C}$, while, for the coldest month (July), mean daily maximum and minimum temperatures are $13^{\circ} \mathrm{C}$ and $3^{\circ} \mathrm{C}$. Mean annual precipitation is $1530 \mathrm{~mm}$, and although rainfall is relatively frequent throughout the year, winter is generally wetter (de Freitas \& Schmekal 2003).

The WGWC is made up of $1300 \mathrm{~m}$ of interconnected passageways with an estimated volume of approximately $4000 \mathrm{~m}^{3}$. The cave has two entrances, an upper entrance and a lower entrance, $14 \mathrm{~m}$ vertically apart. The upper entrance is equipped with a solid door that, when closed, seals the opening, preventing airflow. A stream enters the cave at the lower entrance and leaves through a sump at the other end of the cave. The Cathedral marks the central-cave area, which is a $40 \mathrm{~m}$ long and $13 \mathrm{~m}$ high chamber, the largest in the cave. The Organ Loft Side Passage, which leads from the Cathedral area to the Organ Loft chamber, is a cul-de-sac passage. The lowest part of the cave is the Glowworm Grotto, which is part of the stream passage of the Waitomo River. The Glowworm Grotto is a large chamber approximately $30 \mathrm{~m}$ long and $10 \mathrm{~m}$ wide and has the main displays of the glowworm (Arachnocampa luminosa) in the cave. From here the stream flows $180 \mathrm{~m}$ down through 
a passage and sump before resurging. A description of the WGWC, its physical dimensions, location of monitoring sites and types of instruments used, along with other information on the cave are given by de Freitas and Schmekal (2003, 2006).

Over the past 30 years the WGWC has been the focus of a variety of detailed research projects and is probably one of the most closely studied show caves in the world. Also, as the name implies, the cave fauna are the prime attraction at Waitomo, unlike most show caves. It is different too in that the significance of the cave is not just local. The WGWC is a major tourist attraction, which has played, and continues to play, a vital part in the development of the New Zealand's tourist industry. To large numbers of tourists from both New Zealand and overseas, a visit to the WGWC and caves nearby is a high point of their holiday experience. The WGWC, along with the geothermal areas in and around Rotorua, have come to symbolise the North Island New Zealand tourist encounter. For this reason, the value of the WGWC to New Zealand tourism extends beyond its great commercial importance. It is a natural resource of great significance for which the Government of New Zealand through its Department of Conservation has a major custodial responsibility. It is ironic, therefore, that there are no laws in New Zealand set out specifically to protect caves from exploitation. For new developments or uses of caves there is a generalised Resource Management Act, but apart from that there is a legislative vacuum in New Zealand as far as caves are concerned.

The WGWC has been used continuously as a tourist cave for over 120 years, and over this time several lessons have been learned. Most notably, during the 1970s, it was recognised that conditions in the cave were rapidly deteriorating. There was concern that many changes occurring would be irreversible, but, at that time, little was understood about the cave environment and factors that controlled conditions in the cave. The problem peaked in April 1979 when the cave had to be closed for four months because only four percent of the glowworms had their lights on. On occasions such as this the cost to the region in lost revenue can be considerable. Later that year, in recognition of the fact that the microclimate of the cave is a fundamental element of a cave ecosystem, an intensive study of the microclimate of the WGWC began. This coincided with detailed in situ studies of glowworms and sedimentation processes in the stream that passes through the lower parts of the cave. The work resulted in a number of research papers appearing in the scientific literature, the results of which have been taken into account in setting out cave management guidelines.
Several major decisions on cave management came from the early work, but the main recommendation was that the cave ecosystem, especially the cave air or microclimate, should be carefully monitored. This monitoring should provide long term, high quality data on the atmospheric and other environmental processes that affect the cave ecosystem in general, and the health of the glowworm population in particular. The Waitomo Caves Research Committee, reporting in 1982, emphasised the need to establish sustainable resource management guidelines to protect the cave environment in terms of the glowworm ecology and speleothems, and at the same time, guarantee visitor safety (de Freitas 1990, 1996). The protection mechanism should ensure that changes to the cave microclimate and low glowworm numbers experienced in the late 1970s are avoided in the future.

Monitoring of conditions within the WGWC began in earnest in 1983. Initially, monitoring was developed as a follow-on from detailed research instigated and supervised by the Waitomo Caves Scientific Research Group, which was established in 1974. A relatively large amount of microclimate data has been collected since 1983 using standardised procedures. However, collection and assembly of data relied on cave guides and administrative staff taking readings and maintaining instruments themselves. Gaps in the data and poor equipment maintenance reduced the quality of the data. Moreover, as the data set was assembled manually, processing and analysis were difficult and time consuming. The accumulated microclimate data gathered in this way was transferred from paper records to a computer-compatible database and analyzed. The results showed that there are many large gaps in the data record and that reliability of measurements at certain times and for certain extended periods is suspect due mainly to lack of equipment maintenance and instrument failure.

In the latter part of 1993 a scheme was proposed for improving the quality and quantity of cave climate data. Continuous monitoring, employing remote automated systems using electronic sensors and data loggers, was recommended. Data loggers allow for the collection of large amounts of data from a variety of sensors at a relatively low cost. Also, problems of observer error are removed, and data are presented in a form amenable to computer analysis. By the start of 1994, a computerised electronic monitoring system was installed in the cave at four different sites to measure rock temperature at different depths below the rock surface, air temperature, humidity and the speed and direction of air flow. Information is accumulated continuously by data loggers as well as fed directly to monitors located in the cave supervisor's control room. 


\section{IMPACTS}

Using a cave for tourism while at the same time ensuring the cave's environment is not damaged or the resource depleted through microclimatic impacts is no minor challenge. That a cave may be little more than a place for sightseeing and adventure is a perception held by many tourists. However, for the cave manager, the cave should be seen as a valuable environmental asset. Moreover, it should be considered to be a non-renewable resource, as damage to cave features may take several human lifetimes to recover, or never recover at all. To ensure a balance between preservation and use of cave resources, an appreciation of the precise nature of the cave resource is crucial. It is not sufficient to focus entirely on cave usage levels or carrying capacity; rather, the issue is more one of determining environmental management techniques that are appropriate to a particular cave in the light of environmental conditions within the cave that prevailed prior to human use. The real issue, therefore, is one of visitor impact management.

There are direct and indirect, external and internal impacts to consider. Indirect impacts are mainly those caused by so-called surface effects in the vicinity of the cave resulting from agriculture, the construction of car parking areas, walking tracks, kiosks, toilets, hotels and motels, and may add to the direct underground impacts by affecting sediment and impurities in runoff into streams, cave passages and caverns.

Direct impacts include breakage of speleothems. The threat of vandalism when the cave is closed often necessitates elaborate security structures and fixtures. Direct impacts that are particularly relevant to cave microclimate include: construction of access routes through caves and entrance modifications that alter cave airflow, and elevated air temperatures from the accumulated body heat from large numbers of visitors. The build-up of carbon dioxide in the cave from human breath can combine with moisture to corrode speleothems and bedrock. Dust accumulation in the cave can also be a problem. Cave dust is composed of lint from clothes, hair, and flakes of dry skin that provide additional food sources for carbon dioxideproducing bacteria and from microbial activity in general. Similarly, abandoned wooden walkways and railings provide food sources for microorganisms, resulting in decomposition and increased carbon dioxide emissions into the cave air (Cigna 2005, Russell \& MacLean 2008). Cave lighting may heat up and dry the ambient air, inhibiting speleothem growth. Broad spectrum emission lighting commonly leads to the growth of "lampenflora" (algae and mosses) on clastic sediments, speleothems and cave walls; narrow spectrum and relatively cool LED lights reduce lampenflora growth and heat output. Many of these impacts are cumulative and often lead to irreversible degradation to the cave ecosystem. Fig. 1 shows the key parameters and processes affecting caves such as the WGWC and the associated impacts.

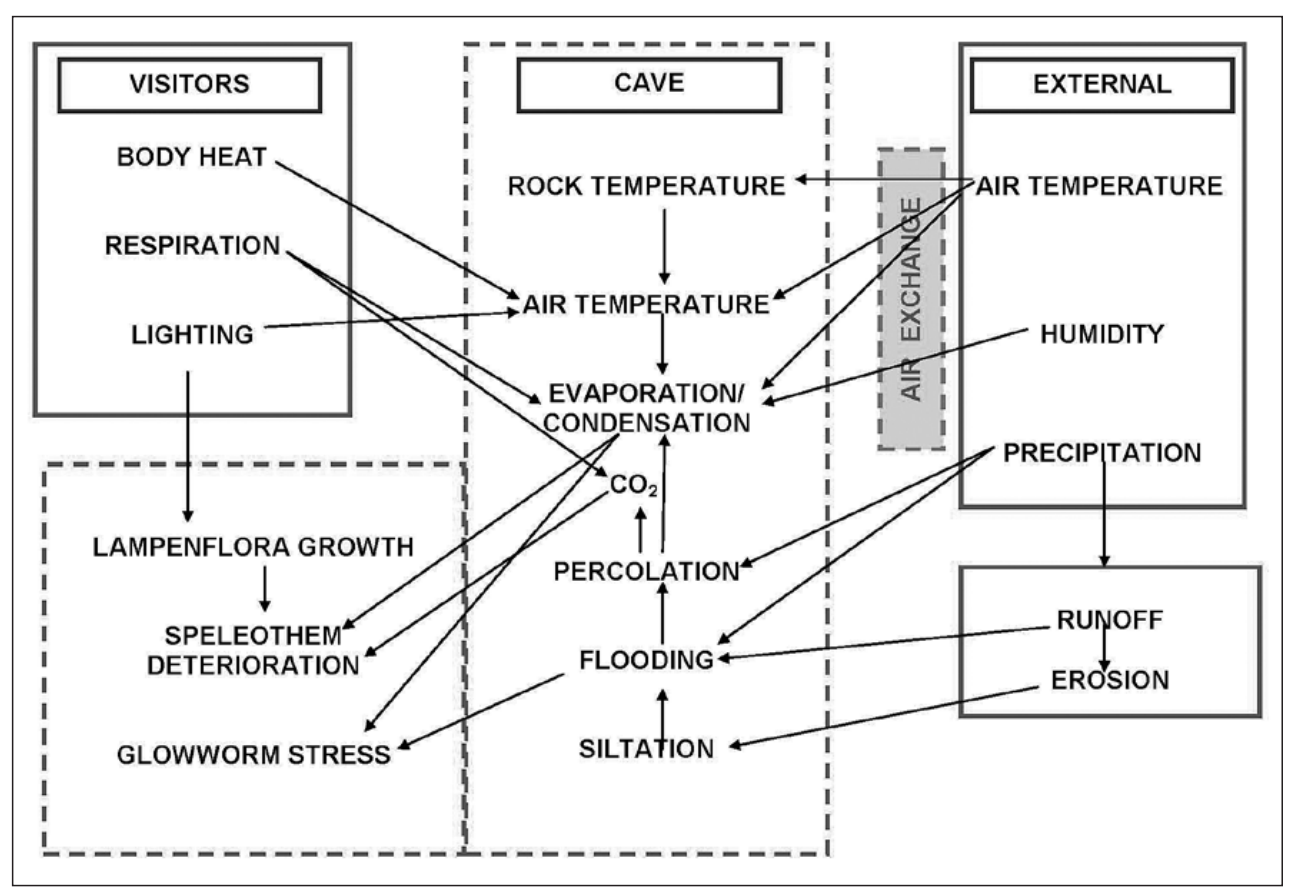

Fig. 1: Key parameters and processes affecting show caves such as the Waitomo Glowworm Cave, New Zealand. 


\section{MICROCLIMATIC INDICATORS}

\section{Airflow}

Airflow in the WGWC has been studied in detail by de Freitas et al. (1982) and shown to be the key component of a cave's microclimate (de Freitas \& Littlejohn 1987). The speed and direction of flow is determined by the difference between the density of the outside and inside air (de Freitas et al. 1982). Since air density is mainly a function of air temperature for caves with a small vertical extent, temperature can be used as the main indicator of airflow (de Freitas et al. 1982). When the outside air is cooler and thus denser than the cave air, the warmer cave air rises and flows towards and then through the upper entrance and is replaced by cold air at the lower entrance. This upward flow is referred to as "winter" flow (colder air outside the cave), although it can occur at any time of year. When cave air is cooler and denser than the air outside the cave, it flows down through the cave and out the lower entrance (de Freitas et al. 1982). This downward flow is referred to as "summer" flow (warmer air outside the cave), although it can occur at any time during any day of the year, depending on the climate regime of the region in which the cave is located. In transitional times when the temperature gradient inside and outside the cave is small, there is little or no airflow.

Air exchange with the outside is a major control on cave environmental conditions. It determines the extent to which the heat and moisture state of the cave environment is similar to surrounding rock or that of the outside air. Air flow in caves should be measured using ultrasonic (acoustic) anemometers, which can reliably sense the very low rates of air movement that can occur in caves. Also, the absence of moving parts make ultrasonic anemometers better suited to harsh cave conditions than alternative methods such as cup or hot-wire anemometers.

\section{Air temperature and humidity}

The thermal and moisture state of the cave air is crucial in determining the condition of the cave environment. A key precept of cave climatology is that the cave atmosphere is a result of the degree to which the effects of advection of heat and moisture from outside the cave are modified by internal heat and moisture transfer processes. In the absence of advection, cave air adopts the thermal and moisture characteristics of the surrounding rock, as in a completely closed cave. Alternatively, air moving through the cave adopts a particular change or "decay" profile as it moves towards a thermal and moisture equilibrium with the surrounding cave rock. Clearly, modification of natural cave entrances or adding new ones, such as might be required for visitor access, will affect air exchange with the outside, leading to unnatural and perhaps damaging warming, cooling or drying of cave surfaces.

The results of earlier work (de Freitas \& Littlejohn 1987) show that heat and mass (moisture) transfer models can be used to approximate longitudinal profiles of temperature and moisture in a cave and help identify and explain changes occurring. The heat and mass transfer processes that determine spatial and temporal patterns of temperature and moisture conditions in a cave are: (i) external air temperature, relative humidity and specific humidity (or dewpoint temperature); (ii) sensible and latent heat transfer to and from the air moving through the cave and the cave surfaces; and (iii) vapour flux between the cave air and cave surfaces. Seasonal patterns show that for an air parcel moving upwards through the cave ("winter flow"), both cave air temperature $(T)$ and specific humidity of the cave air $(q)$ increase with distance into the cave from the lower entrance. This results from a continuous transfer of heat and moisture to the air as it flows through the cave; the negative latent heat flux leads to a cooling of the air and rock surfaces. Ultimately, the air is modified toward a thermal and moisture equilibrium with the cave environment. The increase in $T$ with distance increases the moisture holding capacity of the air, thereby maintaining the vapour gradient. For this reason, evaporation and thus cave drying can occur even when the air appears to be at its saturation point, as the saturation specific humidity is continually increasing. For downward airflow conditions ("summer flow") in the case of the WGWC, $T$ decreases from the upper entrance into the cave as a result of the sensible heat transfer from the air to the cave environment. For "summer flow" conditions the latent (evaporative) heat flux can result in either cooling of the air and rock due to evaporation, or warming from heat liberated during condensation. The cave atmosphere responds rapidly to changes in external air temperature and humidity as a result of the interaction between the cave and outside atmosphere. For upward airflow conditions, the diurnal pattern of $T$ and $q$ within the cave follows the diurnal pattern of the outside air, and both $T$ and $q$ are higher than outside over the full diurnal cycle. The amplitude of the diurnal variation of $T$ and $q$ decreases with distance into the cave as a result of the transfer of heat and moisture from the cave surfaces to the moving air.

Unlike changes typical of air temperature and relative humidity outside, cave temperature and relative humidity can increase and decrease together as a result of the advection of both heat and moisture through the cave (de Freitas \& Littlejohn 1987). The seasonal and 
short term trends in cave climate show that during winter the cave experiences a net loss of heat and moisture. This results in cooling of the cave rock and a depletion of the moisture within the cave. In summer, net gains of heat and moisture result in an increase in rock temperature and the addition of moisture to the cave in the form of condensation. The seasonal patterns, particularly specific humidity, reflect a longer period of moisture loss than moisture gain.

Research on the WGWC has shown that manipulation of the cave microclimate, such as for the benefit of cave fauna, may be possible (de Freitas 1996). For example, air temperature and humidity can be increased in winter by sealing off the upper entrance, thereby restricting circulation of air through the cave. On the other hand, keeping in mind that there is strong cave drying during "winter flow", humidity levels could be raised and evaporation suppressed by increasing moisture in the cave available for evaporation, either by regular wetting of paths and walls or by establishing pools in various parts of the cave. In summer, reduced warming of the cave would result from sealing the lower entrance. Clearly, however, any manipulation of the climate would have to take into account other effects on the cave ecosystem. Such "engineering" approaches to cave management are not usually the preferred option.

Finally, it is essential that the psychrometric method of measuring air temperature and humidity is employed when gathering cave climate data. This involves the use of ventilated "dry bulb" and "wet bulb" thermal sensors (thermometers). Measurements of the dry bulb temperature (air temperature) and wet bulb depression (dry bulb minus wet bulb temperature) are applied to a standard psychrometric formula to calculate any of the various expressions of humidity, usually specific humidity or mixing ratio, although vapour pressure and dewpoint temperature can be equally useful expressions of humidity in cave microclimate research. In many cases, use of relative humidity and absolute humidity should be avoided as these expressions of humidity are dependent on air temperature as well as the moisture content of the air. On the other hand, when air with a given relative humidity moves to another environment with a different air temperature, the difference between the absolute humidity in the two conditions indicates the amount of water to be deposited or evaporated.

Hygrometric methods for measuring relative humidity rely on moisture-sensitive materials (such as lithium chloride or animal hair) and are thus an indirect measurement of, or proxy for, the moisture content of the air. Measurement error in air approaching saturation (i.e. at high levels of relative humidity), such as exists in many caves, is usually both large and non-linear.

\section{Carbon dioxide}

The concentration of carbon dioxide $\left(\mathrm{CO}_{2}\right)$ in cave air is determined by the balance between the rate of input of $\mathrm{CO}_{2}$ to the cave and losses (sinks) of $\mathrm{CO}_{2}$. Sources of carbon dioxide in show caves such as the WGWC are:

1) respiration of people in the cave;

2) outgassing from water flowing through the cave and from vadose waters;

3) oxidation of organic material and respiration by micro-organisms;

4) diffusion of soil gas through soil and rock into the cave.

In the absence of air exchange with the outside environment, the concentration of $\mathrm{CO}_{2}$ in the cave air is a function solely of the rate of $\mathrm{CO}_{2}$ input from sources 1 to 4 above.

Sinks of carbon dioxide in caves are:

1) airflow and air exchange with the outside (ventilation);

2) solution in undersaturated cave water; and

3) diffusion through (porous) cave walls.

$\mathrm{CO}_{2}$ concentration in the cave air is normally greater than that outside, so ventilation is the major control on the concentration of $\mathrm{CO}_{2}$ in cave air.

In show caves, humans are clearly the major cause of elevated concentrations of $\mathrm{CO}_{2}$, directly through respiration and, to a lesser extent, indirectly by promoting the activity of bacteria and other micro-organisms that feed on organic matter including skin and hair shed from the human body. People exhale air that is slightly depleted in oxygen and enriched in $\mathrm{CO}_{2}$ (approximately $4 \% \mathrm{CO}_{2}$ ). Concentrations depend on visitor numbers and ventilation rates through the cave. A single person exhales $\mathrm{CO}_{2}$ at approximately $17 \mathrm{l} \mathrm{hr}^{-1}$ (Marion 1979); thus a tour group of 200 visitors expels about $3360 \mathrm{l} \mathrm{hr}^{-1}$. Concentrations of carbon dioxide of up to $5000 \mathrm{ppm}$ have been recorded in the WGWC (de Freitas 1996; de Freitas \& Banbury 1999). The allowable level that should be specified in cave management guidelines is open to debate (Dragovitch \& Grose 1990). Added to this is the concern that when carbon dioxide concentrations exceed about $2400 \mathrm{ppm}$ in the Waitomo caves, water can combine with $\mathrm{CO}_{2}$, forming a weak acid, which can lead to corrosion of limestone features of the cave (McCabe 1977). For this reason, $2400 \mathrm{ppm}$ is taken as the maximum permissible level to which $\mathrm{CO}_{2}$ concentrations should be allowed to rise in the Waitomo caves generally. It is based on the work of McCabe (1977) and Kermode $(1974,1980)$ conducted in the Waitomo region. The reliability of this threshold value as a universal management guideline to prevent corrosion of speleothems requires further research. Since the work of McCabe (1977) and Kermode (1980), Baker and Genty (1998) have considered environmental pressures on conserving cave spe- 
leothems in the context of effects of changing surface land use and increased cave tourism. They make the point that the calcium ion concentration of the drip waters is important. When it is low, a small increase in cave air $\mathrm{CO}_{2}$ can cause corrosion, whereas when it is high, speleothem growth may be maintained at higher $\mathrm{CO}_{2}$ concentrations in the air.

The results of work by de Freitas and Banbury (1999) show that rate of build-up of carbon dioxide in cave air under conditions of high visitor usage is rapid, and that a rise in $\mathrm{CO}_{2}$ concentration of $800 \mathrm{ppm}$ or more can occur in a relatively short period of time (90 minutes). Dispersion of the $\mathrm{CO}_{2}$ enriched air is surprisingly efficient, spreading even to the most remote and poorly ventilated parts of the WGWC, even when flow-through ventilation of the cave was severely restricted by closing off the upper entrance of the cave. Dispersion is primarily upwards, suggesting that the process is thermally driven. The cause is the combined effect of respired air and metabolic heat from the gathering of people warming the air within the assembled group (de Freitas et al. 1985). The result is a thermal plume that moves and mixes by convection upwards. The role and efficiency of "chimney effect" ventilation of the cave was demonstrated by the relatively fast decline in $\mathrm{CO}_{2}$ once the upper entrance was opened (de Freitas \& Banbury 1999). Recovery rates were rapid, with about eighty percent recovery occurring within one hour of the carbon dioxide source being removed. Full flushing occurs within approximately two hours (de Freitas \& Banbury 1999).

It should be noted that although $\mathrm{CO}_{2}$ alone is denser than air, respired $\mathrm{CO}_{2}$ is well mixed and will not separate from an air parcel and settle to the floor of the cave. However, if $\mathrm{CO}_{2}$ enriched air enters the cave at floor level and its temperature is below that of the surrounding air, or its density is exactly the same (temperature and humidity), then it is possible for the carbon dioxide enriched air to exist for some time as a layer at floor level until molecular diffusion or turbulence mixes the $\mathrm{CO}_{2}$ enriched air into the larger volume of air surrounding around it. This could be important in circumstances where the source of $\mathrm{CO}_{2}$ in the cave is water (McCabe 1977), respiration by micro-organisms or diffusion of soil gas through soil and rock into the cave and vadose solutions entering cave, especially if accompanied by cool or stable ambient conditions. An interesting account on $\mathrm{CO}_{2}$ "stratification" has been provided by Badino (2009) in a paper titled "The Legend of Carbon Dioxide Heaviness".

Previous recommendations for visitation rates at the WGWC have been based on the number of people in the cave per hour. Given that for some time it has been recognised that the Organ Loft (cul-de-sac passage) is a trap for $\mathrm{CO}_{2}$ and that concentrations increase rapidly with visitors present, tour groups that visit this area of the cave have been strictly controlled (de Freitas 1996). However, the results of this work show that $\mathrm{CO}_{2}$ levels in the Organ Loft are not solely a response to $\mathrm{CO}_{2}$ emissions at that site alone. In fact, concentrations reflect $\mathrm{CO}_{2}$ emissions elsewhere in the cave and are cumulative (de Freitas \& Banbury 1999). This does not apply to certain other locations; namely those at lower levels, such as the all-important Glowworm Grotto. Clearly, the cave management implications of this are important.

\section{Radon}

Radon ( $\mathrm{Rn})$ is an odourless, colourless, inert, radioactive gas. There are several distinct isotopes of radon coming from the decay of different sources, but ${ }^{222} \mathrm{Rn}$ with a halflife of 3.825 days, is the most commonly occurring isotope in the natural environment, including caves (Cigna 2005; Gunn 2004; Gunn et al. 1991; Hyland \& Gunn 1992). ${ }^{222} \mathrm{Rn}$ is released from the radioactive decay of uranium salts weathered from rock and may accumulate on dust and water droplets in air pockets with poor ventilation. If this air is inhaled, the alpha and beta radiation present may cause cell damage and increased risk of cancer. The risk depends on both the concentration of radon and total exposure time. The International Commission on Radiological Protection (ICRP) defines a "safe" level as under about three times the normal background level to which an average person is exposed in normal daily living; that is, less than $1000 \mathrm{~Bq} \mathrm{~m}^{-3}$ (Becquerels per cubic metre). Usually, prolonged exposure above this level is required to elevate risks to human health, normally expressed as "working level hours" (Gunn 2004). Radon build-up at any given site in a cave depends largely on ventilation rates.

In the Waitomo area the single entrance Aranui cave has the highest concentrations $\left(12000 \mathrm{~Bq} \mathrm{~m}^{-3}\right)$, but these are highly variable in space and time, falling at times to $150 \mathrm{~Bq} \mathrm{~m}^{-3}$ (Robb 1999). These concentrations of radon do not affect tourists whose exposure time is short, but are potentially of significance for cave tour guides and other cave workers. In the WGWC, concentrations ranged from 50 to $2000 \mathrm{~Bq} \mathrm{~m}^{-3}$ (Robb 1999). Manipulation and control of cave ventilation along with minimising exposure times for cave workers are the key management tools for radon in caves.

\section{Condensation}

The condensation/evaporation process to and from cave rock plays a variety of roles in speleogenesis, but two of these are particularly important. The first occurs where water condensing onto cave rock surfaces that are made of a soluble rock mineral (calcite, dolomite, gypsum, halite, carnallite etc.) is undersaturated with respect to the 
mineral, so that the potential exists for dissolution to occur. This process, called condensation corrosion (James 2004), may create surface impressions on speleogen features. Water from condensation can cause this because its chemistry makes it aggressive. Carbon dioxide, water and calcium carbonate (limestone or calcite) react to give soluble calcium and carbonate ions $\left(\mathrm{CO}_{3}^{-}\right)$in water Condensation water becomes considerably more corrosive if it contains substantial amounts of dissolved carbon dioxide. In show caves visitors breathe out warm air saturated with water vapour, together with greater than $4 \%$ by volume carbon dioxide, at a temperature usually much higher than the cave air. The moisture in this air containing high concentrations of carbon dioxide might condense as it comes into contact with the colder cave air and walls.

The second process occurs during times when conditions in the cave cause high rates of evaporation of condensation water on cave rock surfaces. The removal of water and carbon dioxide from saturated solutions of calcium and hydrogen carbonate ions causes precipitation of calcite. This process produces soft unattractive microcrystalline, flaky deposits of calcite. This cycle of condensation and evaporation of condensate is believed to enhance condensation corrosion (TarhuleLips \& Ford 1998).

Condensation in caves has been addressed in the research literature, such as by Cigna and Forti (1986) and more recently by Dublyansky and Dublyansky (2000), Dreybrodt et al. (2005), Auler and Smart (2004) and de Freitas and Schmekal $(2003,2006)$. The results are also relevant to aspects of tourist cave management. Ideally, there would be no need to induce either condensation or evaporation in a cave. Intuitively, one would think that the best course would be to keep the system at equilibrium to avoid both drying-out and excessive moisturizing, both of which could be detrimental to the cave formations. However, for show caves where care and proper management is a concern, condensation/evaporation can be predicted or controlled by controlling ventilation. Because cave rock surface temperatures do not vary much, condensation is essentially a function of cave air temperature and the processes that affect it; mainly, air exchange with the outside.

The work on $\mathrm{CO}_{2}$ in the WGWC (de Freitas \& Banbury 1999), and later the relevance of this for condensation (de Freitas \& Schmekal 2003, 2006), provide insight into the environmental effects of management-induced changes. There is need for more work on caves in other climate regimes. Future research should also aim to develop an understanding of the role of condensation in the water and energy balance of caves. Other work might focus on spatial variation of condensation through large caves and factors that affect the geochemical composition of condensate.

\section{MONITORING}

Cave managers need to decide what is the desired or optimal level or range of environmental conditions that should exist within the cave. This requires an appropriate and reliable monitoring system and identification of key indicators; for example, a given range of temperature and humidity, a maximum allowable vapour pressure deficit (to indicate cave drying); or a maximum allowable carbon dioxide concentration. Management strategies should also take into account sensitivities of cave fauna, which are often vulnerable to minor changes of light, moisture and heat. Careful monitoring enables cave managers to assess the consequences of change and modify management strategies accordingly. Cave monitoring should include physical, biological and social (visitor) variables. The purpose of environmental monitoring is to: a) assess the impact of human activity in the cave; b) expand knowledge of the cave resource by adding a long term dimension to the data collected during initial intensive research; c) identify environmental seasons, cycles, changes and trends that may impact the cave or cave ecosystem; d) assess the impact on the cave of management practices such as cave microclimate control, desilting and lampenflora removal and e) assess the impact of human activity outside the cave, such as changes in land use or to the catchment. The purpose of visitor monitoring is to: a) provide an information/data base to assess the impact of people on the cave and glowworms; b) identify visitor patterns; and c) provide information for auditing and planning.

An essential part of identifying and selecting appropriate variables to be monitored is an understanding of physical and biological processes that comprise the cave system. Good management involves identifying optimal conditions and maintaining them. Identifying relevant questions with correct answers is the key to informed and effective sustainable use and management of show caves. These are: What to monitor? Where to monitor? How to monitor? 
The answer to the question of what to monitor hinges on an understanding of cave microclimate (cave and outside air and related processes) as the key element. Clearly, from the foregoing discussion, there is a need to understand and appreciate the processes operating, so decisions can be made on what to measure. These are cave air temperature; outside air temperature; cave air humidity (specific humidity); outside air humidity (specific humidity and relative humidity); air flow rate; air flow direction (upwards and out through the top entrance, or downwards and out through the lower entrance); rock surface temperature; carbon dioxide; and, if necessary, radon.

The answer to the question of where to monitor depends on the nature, size and morphology of the cave in question. In general, microclimate measurements are required at key (indicator) sites inside the cave and at least one or more sites outside the cave, depending on the size and vertical separation of the lowest and highest entrances.

The answer to the question of how to monitor is important to ensure: a) continuous, reliable operation of instruments; and b) that appropriate microclimate variables are measured with the required level of accuracy. These include the use of: a) automated systems using electronic sensors and data loggers; b) instruments suited to harsh (wet) cave conditions; and c) sensors suited to the range of conditions encountered (i.e. appropriate sensitivity). Data should be collected and stored in electronic form to enable: a) real-time display of conditions (data) being monitored; b) short term diagnosis of conditions in the cave; and c) analysis of trends over many years.

Indicators of impact (as discussed earlier) include: a) change in air temperature from established "natural" or "control" reference points; b) decrease or increase in humidity, or increased vapour pressure deficit, from established "natural" or "control" reference points; and c) rise in carbon dioxide concentration above a maximum set operational level. The issues that arise in implementing all of the above are feasibility and cost of monitoring; choice and representativeness of key indicators; replication and frequency of measurement; quality control; plan for data analysis; and management standards and indicators of impact.

Quality checks and reviews should follow the setting up of long term monitoring programmes. Regular calibration is normal procedure and essential to establish the on-going reliability of the data being collected. All of these things need to be taken into account in assessments of the data record. How data are presented is also important, but may vary depending on whether: a) data are being used by cave managers on an ongoing, regular, short term basis to watch conditions and, if necessary, make short term operational adjustments; b) records are being used for longer term, retrospective analyses of cave microclimate variability, or for post mortems of ecological crises that may occur; or c) data presentations are to be provided as appealing information displays for cave visitors.

\section{Management guidelines for the WGWC}

Significant drying within the WGWC can occur at any time of year; also, evaporation rates can vary considerably over relatively short periods of time, and between sites. A major cause of this is high rates of air exchange between the cave and atmosphere outside, but other factors may also play a part. Cave managers monitor conditions throughout the year and pay close attention to any signs of drying in the cave.

Guidelines for ventilation and microclimate control have been proposed based on studies of the cave microclimate. Various analyses indicate that these guidelines are effective. The aim is to maintain optimal conditions in the cave for both glowworms and tourists, but without causing damage to physical features of the cave itself or affecting sustainable use of the cave. To accomplish this, several factors have to be controlled simultaneously. Rates of evaporation have to be kept low or even negative (i.e. condensation). At the same time, adequate ventilation is required to prevent the build-up of excessive $\mathrm{CO}_{2}$ levels within the cave, but not at the expense of desiccation of the cave milieu or large temperature variation inside. To a large extent this can be achieved by carefully controlling air exchange with the outside. The $2400 \mathrm{ppm}$ limit is the current $\mathrm{CO}_{2}$ threshold stated in the licence agreement under which the WGWC operates.

Operational guidelines are summarised as follows: Close door to upper entrance when:

a) external air temperature is below $10^{\circ} \mathrm{C}$, regardless of humidity level outside; and

b) external specific humidity levels are low (this usually occurs in the cool period of the year, typically between 1700 and 1000 hours).

Open door to upper entrance during:

a) "summer" airflow conditions (i.e. when airflow is downward through the cave), thus allowing for condensation in the cave as well as maximum ventilation at times usually associated with high visitor numbers; and

b) "winter" airflow conditions, when the cave-to-outside-air thermal gradient is weakest; for example, from mid-morning to mid-afternoon, to permit ventilation without excessive drying of the cave. 
It is important to keep in mind the dual effects of ventilation controls; namely, cave moisture and heat on the one hand and carbon dioxide concentration on the other. Should visitation rates increase during the cooler parts of the year, then door-closing routines need to be re-assessed. Reduced ventilation at these times may control desiccation of the cave environment, but may also reduce ventilation to the point where carbon dioxide concentrations rise to undesirable levels. When nights are warm the cave does not recover from the $\mathrm{CO}_{2}$ buildup the day before. Also, lack of ventilation over an extended period means $\mathrm{CO}_{2}$ (and radon) concentrations will increase.

To stabilise cave microclimate, in 1980 a recommendation was made to the cave operators to seal the upper entrance and install an airtight door. As a result, the microclimate of the cave appears to have become more stable. However, subsequent data showed that the door may have been inadvertently left open at times when airflow through the cave is unwanted. The tour guides lead tourist groups into the cave and rely on the last member of the group to shut the door. For a variety of reasons the door may often be left open. To ensure that the door remains shut when required, in 1995 it was recommended that an automatic door closing device be installed, but managed according to ventilation guidelines outlined above.

Disproportionately low minimum air temperatures relative to corresponding maximum temperatures may show up periodically. Likewise, elevated maximum air temperatures out of phase with minimum temperatures may occur at times. These may be due to several factors, including: a) instrument malfunction; b) the thermal effect of increased visitor traffic; and c) the effect of increased rates of air exchange with the outside during periods of the day when the cave entrance door is left open. The occurrence of these and possible effects on the cave environment need to be carefully watched. Formal data-reporting procedures are in place (quarterly or half-yearly). Reports are regularly scrutinised by cave managers to check for continuity of the data record and instrument performance.

Adequate environmental monitoring is vitally important to the proper management of show caves such as the WGWC, but measurement alone is not sufficient. Regular, detailed, formal scientific appraisals of data by qualified personnel are essential. Casual or informal assessments and reliance on low cost options for monitoring are hard to justify for managing such an important national resource. An essential part of identifying and selecting appropriate variables to be monitored is an understanding of physical and biological processes that compose the cave system. Key reference criteria can be used in defining optimal conditions and maintaining them.

Conscientious cave management is concerned with identifying acceptable environmental conditions and maintaining them. It involves adopting appropriate indicators, setting standards to be maintained, and monitoring to allow comparison to that standard. If necessary, operators will modify management strategies if standards cannot be consistently met. The choice of indicator-variables must take into account their representativeness and the feasibility of monitoring them. In the case of the WGWC, the undertaking to continuously (halfhourly) monitor conditions in the cave using automated data collection systems has proved to be worthwhile. However, the quality of microclimate and environmental data collected using automated systems must meet acceptable standards. This is of the utmost importance if the data are to be of value for future analysis of the cave environment and for assessing the effectiveness of cave management techniques. Frequent monitoring at a few representative sites is usually preferable to occasional monitoring at many sites. The monitoring system should take into account the possibility of interference by visitors or vandalism, and intrusiveness of the monitoring equipment. In many cases, the presence of equipment may be built into site interpretation and commentary used during tours of the cave. Monitoring of the same key variables at the same sites should be maintained to give long term comparative data. Identification and analysis of many aspects of ecological well-being or change can best be achieved by considering medium to long term trends in environmental and associated data. The information collected will ultimately contribute to a substantial database essential for overseeing the well being of the cave environment. In addition to being important for short term monitoring of conditions, the data will provide a vital retrospective record should conditions change or problems arise in the future.

\section{THE CHALLENGE OF SUSTAINABILITY}

Unlike New Zealand, Australia has taken seriously the business of conserving limestone environments and managing tourism there. To heighten protection of the precious Jenolan Caves Reserve in New South Wales, 
an amendment to the (Australian) National Parks and Wildlife Act in 1997 brought into force legislation that provides the reserve and the Jenolan, Abercrombie and Wombeyan Caves with the same protection as National Parks. Despite the near legislative vacuum in New Zealand as far as caves are concerned, the news is not all bad. An environmental advisory group (EAG) was established in 1998 to study and preserve the features of the Waitomo caves and manage the regional resource sustainably. The group includes specialist scientists and representatives from the New Zealand Government's Department of Conservation (DoC) and cave owners, along with the main commercial show cave operator in the Waitomo region, Tourism Holdings Ltd (THL), which funds the EAG. The existence and effectiveness of the EAG is a reflection of the dedication of THL and the cave owners to the well-being of several heavily used Waitomo caves.

Current knowledge of the impact of environmental changes in the WGWC and ways to manage them is based on extensive research carried out over many years. Sophisticated automated monitoring systems check air quality, rock and air temperature, humidity and carbon dioxide. Data is downloaded to a central computer every three minutes, monitored on computer screen displays by specialist show cave staff throughout the day, then reviewed regularly by the EAG. Using this information, THL manages the WGWC, including deciding when the upper entrance doors should be opened or closed to control air flows and the number of people who can visit the cave daily. The same diligent, real-time cave environmental management applies to two other caves nearby run by THL, namely, Aranui and Ruakuri caves. But for those who care that the caves are preserved intact for future generations, this is simply good luck given the lack of legislation in place to ensure good management. There is no guarantee that future owners and managers will be so caring.

The successful operation of the EAG hinges on the balance it allows between conservation of natural and cultural resources with tourism operations. It is a model for New Zealand environmental legislators to consider. It provides an opportunity for the New Zealand Government to deal with its dual responsibility for protecting caves and managing tourism. It also provides an opportunity for dealing with long-standing problems of cave ownership and to clearly define obligations of cave owners and commercial operators of leased caves. Reserve trusts could direct energy towards setting priorities, ensuring decisions are appropriate.

\section{REFERENCES}

Aley, T., 1976: Caves, cows and carrying capacity.- In: National Cave Management Symposium Proceedings 1975. Speleobooks, pp 70-71, Albuquerque.

Aley, T., 2010: Management Strategies for Responding to White-Nose Syndrome in Bats.- National Speleological Society News, 68 (2), 10-14.

Auler, A.S. \& P.L. Smart, 2004: Rates of condensation corrosion in speleothems of semi-arid northeastern Brazil.- Speleogenesis and Evolution of Karst Aquifers, 2, 2, 2 .

Badino, G., 2009: The legend of carbon dioxide heaviness.- Journal of Cave and Karst Sudies, 71, 1, 100107.

Baker, A. \& D. Genty, 1998: Environmental pressures on conserving cave speleothems: effects of changing surface land use and increased cave tourism.- Journal of Environmental Management, 53, 165-175.

Cigna, A. A., 2005: Show caves. In: Culver, D.C. and W. B. White (eds.), Encyclopedia of Caves, Elsevier Academic Press, pp. 495-500, London.
Cigna, A. \& P. Forti, 1986: The speleogenetic role of air flow caused by convection.- International Journal of Speleology,15, 41-52.

de Freitas, C.R., 1990: Climate of the Glowworm Cave 1981-1989: Preliminary Analysis and Recommendations. Report to the Waitomo Caves Management Committee and the Department of Conservation. Review commissioned by the Tourist Hotel Corporation, Waitomo.

de Freitas, C.R., 1996: Management of the Glowworm Cave: Two Years of Automated Climate Monitoring - Recommendations and Management Strategies. Report to THC Waitomo Caves, The Waitomo Cave Management Committee and Department of Conservation. Auckland UniServices Ltd. 
de Freitas, C.R., 1998: Cave monitoring and management: The Glowworm Cave, New Zealand. In: Cave and Karst Management in Australasia XII. Proceedings of the Twelfth Australasian Conference on Cave and Karst Management, 10-15 April 1997, Waitomo Caves, New Zealand, 10-15 April 1997, pp. 55-66. Australasian Cave and Karst Management Association, Waitomo, New Zealand.

de Freitas, C.R. \& R.N. Littlejohn, 1987: Cave climate: assessment of heat and moisture exchange.- International Journal of Climatology, 7, 553-569.

de Freitas, C.R. \& K. Banbury, 1999: Build up and diffusion of carbon dioxide in cave air in relation to visitor numbers at the Glowworm Cave, New Zealand.- In: Cave Management in Australasia XIII. Proceedings of the Thirteenth Australasian Conference on Cave and Karst Management, 18-24 April 1999, Mount Gambier, South Australia., pp. 84-89. Australasian Cave and Karst Management Association, Carlton South, Victoria, Australia.

de Freitas, C.R., Dawson, N.J., Young, A.A. \& W.J. Mackey, 1985: Microclimate and heat stress of runners in mass participation events.- Journal of Climate and Applied Meteorology, 24, 184-191.

de Freitas, C.R., Littlejohn, R.N, Clarkson, T.S. \& I.S. Kristament, 1982: Cave climate: assessment of airflow and ventilation.- Journal of Climatology (later International Journal of Climatology), 2, 383-397.

de Freitas, C. R. \& A. Schmekal, 2003: Condensation as a microclimate process: Measurement, numerical simulation and prediction in the Glowworm Cave, New Zealand.- International Journal of Climatology, 23, 557-575.

de Freitas, C.R. \& A. Schmekal, 2006: Studies of condensation/evaporation processes in the Glowworm Cave, New Zealand.- International Journal of Speleology, $35,2,75-81$.

Dragovitch, D. \& J. Grose, 1990: Impact of tourists on carbon dioxide levels at Jenolan Caves, Australia: an examination of microclimate constraints on tourist cave management.- Geoforum, 21, 1, 111-120.

Dreybrodt, W., Gabrovsek, F. \& M. Perne, 2005: Condensation corrosion: a theoretical approach.- Acta Carsologica, 34, 2, 317-348.

Dublyansky, V.N. \& Y.V. Dublyansky, 2000: The role of condensation in karst hydrogeology and speleogenesis.- In: Klimchouk, A. et al.(eds.) Speleogenesis: Evolution of karst aquifers. National Speleological Society, pp. 100-111, Huntsville, Alabama, USA.
Gillieson, D., 1996: Caves: Processes, Development and Management. Blackwell, Oxford, England, 325 pp.

Gunn, J., 2004. Radon in caves.- In: Gunn, J. (ed.). Encyclopedia of Caves \& Karst Science. Fitzroy Dearborn, pp. 617-619, New York \& London.

Gunn, J., Fletcher, S. \& D. Prime, 1991: Research on radon in British limestone caves and mines, 19701990.- Cave Science, 18, 2, 63-65.

Hyland, R. \& J. Gunn, 1992: Caving risks,- New Scientist. $135,1838,47$.

James, J.M., 2004 Condensation corrosion.- In: Gunn, J. (ed.). Encyclopedia of Caves \& Karst Science. Fitzroy Dearborn, pp. 240-241, New York and London.

Kermode, L.O., 1974: Glowworm Cave Waitomo: conservation study.- New Zealand Speleological Bulletin, 5, 329-344.

Kermode, L.O., 1980: Cave corrosion by tourists.- In: Proceedings of the Third Australasian Conference on Cave Tourism and Management, 10-15 May 1979, Mt Gambier, South Australia, pp. 97-104. Australasian Cave and Karst Management Association, Carlton South, Victoria, Australia.

Marion, J.B., 1979: General Physics with Bioscience Essays.- Wiley, 206 pp., New York.

McCabe, B., 1977: The Geochemistry of Ground Water Solutions Entering Limestone Caverns.- MSc dissertation. University of Waikato, pp. 145.

Robb, N.R., 1999: Radon in Waitomo Caves.- MSc thesis. The University of Auckland, pp. 202.

Russell, M.J. \& V.L. McLean, 2008: Management issues in a Tasmanian tourist cave: Potential microclimatic impacts of cave modifications.- Journal of Environmental Management, 87, 474-483.

Tarhule-Lips, R.F.A. \& D.C. Ford, 1998: Condensation corrosion in caves on Cayman Brac and Isla de Mona.- Journal of Cave and Karst Studies, 60, 2, 8495.

Wilde, K.A., 1986: An historical review of cave and karst conservation and management in New Zealand 1889-1985.- In: Proceedings of the Sixth Australasian Conference on Cave Tourism and Management, 1218 September 1985, pp. 80-92, Australasian Cave and Karst Management Association, Waitomo, New Zealand. 